DOI https://doi.org/10.30525/978-9934-26-047-6-21

\title{
ASSESSMENT OF THE ECOLOGICAL STATE OF WATER BODIES IN KYIV BY COMMUNITIES OF MACROPHYTES, FISH AND BIRDS
}

\author{
Kovalenko Yu. O. \\ Ph.D.,
}

Lead Engineer at Department of Biology of Fish Reproduction Institute of Hydrobiology of National Academy of Science of Ukraine Kyiv, Ukraine

\section{Prychepa M. V.}

Candidate of Biological Science,

Researcher at Department of Biology of Fish Reproduction, Institute of Hydrobiology of National Academy of Science of Ukraine Kyiv, Ukraine

\section{Prokopuk M. S.}

Candidate of Biological Science,

Researcher at Laboratory of Preservation and Biodiversity Renewal Institute for Evolutionary Ecology of National Academy of Science of

\section{Ukraine}

Kyiv, Ukraine

The pace of urbanize rapidly every year more and more curtails the area of natural habitat of most species of wild animals, making it more fragmented. Because of this, the preserved natural landscape within the city boundaries is of great importance for the conservation of regional or global biodiversity [1, p. 90].

Kyiv is the capital of Ukraine, has a different degree of impact from human activity - this makes it possible to compare the ecological state of the environment in highly urbanized areas of the city with little-transformed areas of the city. This can be done by assessing the biodiversity of individual lakes in the city, especially the communities of higher aquatic plants that are interconnected with other communities, in particular fish and birds, by powerful topical and trophic connections. The rupture of these connections due to anthropogenic load can act as a destructive factor in relation to the structural and functional part of the aquatic ecosystem. 
Purpose: To display the consequences of impact from human activities on the environment in terms on indicators of communities of higher aquatic plants, ichthyofauna, as well as waterfowl on the lakes that are located in different parts of the city.

Materials and methods. The studies were carried out during 2015-2020 on two lakes. Experimental Lake Luhove - located in a highly urbanized area of the city, due to this, it is excessively polluted with various fractions of oil products, which has a negative effect on the biodiversity of the entire ecosystem. This is indicated by the data on the content of toxic compounds in the aquatic environment [2, p. 312].

The conditionally controlled lake Almazne is located in the north-eastern part of the city. A mixed forest grows around it, and there is also a cooling channel for a thermal power plant. The lake has a large area and a favorable geographic location far from intensive industrial load. Unlike Lake Luhove, a significant part of the bottom of Lake Almazne consists of sands - this affects plant communities and the processes of self-purification of the reservoir.

For the study were used the conventional hydrobotanical [3, p. 105-117], hydrobiological [4, p. 44-46], ichthyological [4, p. 164, 172] and ornithological technique [5, p.14-15, 21]. Assessment of water quality was carried out by bioindication methods using qualitative features of communities of higher aquatic plants (macrophytes) [6, p.42-43].

Results. The flora of Lake Luhove is extremely impoverished (there are 6 species of macrophytes), which are three times less than in Lake Almazne (18 species). The classical ecological-coenotic profile was transformed: it is represented by a belt of an emergent plants and a fragmentary belt of hydrophytes, in which synusia of duckweeds and coenoses of Ceratophyllum demersum L. which occur sporadically (sometimes the co-dominant is Najas marina L.). There are no species-indicators of high quality water. A half of the species list of macrophytes distributed on Lake Luhove are representtatives of the wetland complex - the indicators of increased anthropogenic eutrophication of water bodies [7, p. 46-47]. This gives grounds to assert about the transformation of the ecosystem. Whereas in Lake Almazne, rheophilic-limnophilic and free-floating communities can be found [8, p. 107]. Macrophytes are represented by a complex of Potamogeton with leaves floating on the surface; Elodea canadensis Michx., which is quite sensitive to contamination. The assessment of water quality using the Macrophyte Index showed that Lake Luhove can be characterized as a reservoir that belongs to the $\mathrm{V}$ class of water quality (very dirty), Lake Almazne - to the II class (clean). 
Next, we analyzed the species composition of the ichthyofauna of the studied lakes. It was found that 18 species of fish live in Lake Almazne, and 11 species in Lake Luhove [2, p. 313]. Lake Luhove is dominated by the most adapted species, in particular the Carassius auratus (L) and Alburnus alburnus $(L)$. There were a small number of species that adapted to the bottom mode of life. The small number of carnivorous species indicates unfavorable living conditions. It was also characteristic that in the experimental lake there were two fish species that were absent in the control lake: Misgurnus fossilis (L.) and Perccottus glenii (Dybowski). Perccottus glenii is an atypical invasive species for the lakes of Kyiv. Their presence indicates a violation of the natural balance in the ecosystem of this lake. In Lake Almazne, we identified Lepomis gibomis (L), which is also an invasive species and tends to settle in reservoirs rich in aquatic vegetation. It should be noted the presence of a greater number of predators ( 5 species) - this indicates a relatively healthy state of the ecosystem.

Also an important component of the aquatic environment is the presence of water and near-water birds. The species composition of the birds of Lake Luhove was 12 species, among which there were practically no specialized ones. This is due to the destruction of natural biotopes due to excessive anthropogenic load.

Lake Almazne has an order of magnitude more species - 40 species of waterfowl and near-water bird species. Among them there are 8 nesting species. The rest were recorded during the period of food and seasonal migrations. It should be mentioned that the lake has many ecological niches for different bird species. On this lake, there were 3 times more plants and 2 times more fish. This attracts birds such as: Gavia stellata (L), Sterna hirundo (L), Podiceps cristatus (L) (nests up to 22 pairs), Aythya marila (L), Podiceps grisegena (Boddaert). In addition, the territory of the lake water area is a place for the migration routes of certain bird species, among which there are rare species: Sterna albifrons (Pallas), Pandion haliaetus (L), Mergus serrator (L), Bucephala clangula (L), Podiceps auritus (L), Melanitta fusca (L). The lack of transformation has a beneficial effect during the spring flood. This is facilitated by the community of beavers living on Lake Luhove, which is a biotic factor in maintaining the environment. Due to the flooding of the shores, new ecological niches appear, which are important for the existence of specialized species of aquatic and semiaquatic animals. Also, these niches are used by phytophilous fish as spawning grounds and by birds for nesting. The absence of certain biotopes occupied by specific bird species makes it impossible for their existence in Lake Luhove. Excessive impact from human activities and geographically 
unfavorable location around the industrial area of the city make this water body unsuitable even for migratory bird species.

Conclusions. Research results indicate that Lake Almazne provides an environment for the existence of a significant number of representatives of fauna and flora, which cannot be said about Lake Luhove. Our data confirm the reliability of the indicators of communities of higher aquatic plants, fish and birds for their use in the initial diagnosis of the state of ecosystems.

\section{References:}

1. Goddard M. A., Dougill, A. J., Benton, T. G. Scaling up from gardens: biodiversity conservation in urban environments. Trends in ecology \& evolution. 2010. 2. Vol. 5 (2). P. 90-98.

2. Причепа М.В., Коваленко Ю.О. Рибні господарства як осередки біологічного різноманіття. Actual problems of national sciences modern scientific discussions: Collective monograph. University of Life Sciences in Lublin. Lublin, Poland: Baltija publishing. 2021. P. 301-325.

3. Гидроботаника. Методология, методы / Научные редакторы В.Г. Папченков, А.А. Бобров, А.В. Щербаков, Л.И. Лисицына. Рыбинск, 2003. $188 \mathrm{c}$.

4. Романенко В.Д., Арсан О.М., Давидов О.А., Дяченко Т.М., Євтушенко М.Ю. Методи гідроекологічних досліджень поверхневих вод. Київ: Логос. 2006. 408 с.

5. Фесенко Г.В., Бокотей А.А. Птахи фауни України: польовий визначник. Київ: Українське тов-во охорони птахів. 2002. 416 с.

6. Мальцев В.І., Карпова Г.О., Зуб Л.М. Визначення якості води методами біоіндикації. К.: НЦУБМ НАН України, ШНЕКО. $2011.112 \mathrm{c}$.

7. Zub L.N., Prokopuk M.S., Pogorelova Yu.V.Species Composition of Higher Aquatic Plants of Urban Water Bodies as the Index of Environment Quality. Gidrobiol. Zhurn. 2019. Vol. 55, (2). P. 43-53.

8. Романенко О.В., Арсан О.М., Кіпніс Л.С., Ситник Ю.М. Екологічні проблеми Київських водойм і прилеглих територій. Київ: Наукова думка. 2015. 189 с. 